\title{
Short communication: Preliminary investigation into the effect of freezing and a cryopreservant on the recovery of mastitis pathogens from ewe milk
}

\author{
E. M. Smith, ${ }^{1}$ E. M. Monaghan, S. J. Huntley, and L. E. Green \\ University of Warwick, School of Life Sciences, Gibbet Hill Road, Coventry, CV4 7AL, United Kingdom
}

\begin{abstract}
The objective of this study was to investigate the recovery of bacteria from ewe milk after freezing for 4 or $8 \mathrm{wk}$ with and without the addition of glycerol as a cryopreservant. A total of 50 udder-half milk samples with a known range of bacterial species were selected, stored, and analyzed in 5 treatment groups: time zero; frozen for 4 wk with, and without, glycerol; and frozen for $8 \mathrm{wk}$ with, and without, glycerol. A lower recovery was observed in all bacterial species studied after freezing. Samples containing fewer than $100 \mathrm{cfu} / \mathrm{mL}$ came from ewes with a lower somatic cell count and were more likely to be bacteriologically negative after freezing than those above this threshold. The addition of glycerol increased recovery of gram-negative bacteria after freezing, although this requires further study to draw strong conclusions. The effects on gram-positive species were inconsistent. We conclude that although the addition of glycerol had a small beneficial effect on the sensitivity of detection of bacteria from frozen sheep milk, sensitivity was highest in cultures from fresh milk.
\end{abstract}

Key words: sheep milk, freezing, cryopreservant

\section{Short Communication}

Mastitis, inflammation of the mammary gland, is a common disease of dairy and meat sheep, which presents as a clinical disease or subclinical IMI. Both forms can affect milk production and lead to decreased weight gain in suckling lambs (Fthenakis and Jones, 1990). Antibiotic therapy is used to treat clinical disease but is rarely used as a routine treatment for subclinical infection at drying off in meat sheep. As a consequence, the udders of meat ewes are exposed to many pathogens over a lifetime, and the prevalence of subclinical infection is estimated to range from 5.5 to $7.0 \%$ in the UK

Received December 8, 2010.

Accepted May 10, 2011.

${ }^{1}$ Corresponding author: edward.smith@warwick.ac.uk
(Watkins et al., 1991) and is $28.8 \%$ in Canada (Arsenault et al., 2008).

The bacterial species isolated from IMI in meat sheep are similar to those isolated from other livestock, and include Escherichia coli, Staphylococcus aureus, CNS, and streptococcal species (Watkins et al., 1991). In addition, Mannheimia (formerly Pasteurella) haemolytica is a common cause of IMI (Watkins et al., 1991). Bacteriological culture of milk samples remains the gold standard for identification of pathogens in milk, and freezing samples before analysis is common practice. A variety of freeze and culture techniques have been investigated to determine their effects on the recovery of pathogens from bovine and caprine milk. The only study to date reporting the effect of freezing sheep milk on recovery of bacteria using culture was by Clements et al. (2003), who froze 60 samples for 1 wk. Despite somewhat conflicting reports, where an effect is detected, freezing cow milk generally results in an increase in the isolation rate of staphylococci (Schukken et al., 1989; Villanueva et al., 1991; Sol et al., 2002), has variable effects on the isolation rate of streptococci (Villanueva et al., 1991; Sol et al., 2002), and leads to a decrease in the isolation rate of $E$. coli (Schukken et al., 1989) from bovine milk. In contrast to studies of bovine milk, Staph. aureus was not isolated from 2 (100\%) known positive ovine milk samples after storage at $-21^{\circ} \mathrm{C}$ for 1 wk (Clements et al., 2003). One possible method of attenuating this negative effect of freezing is to use a cryopreservant such as glycerol, which has been shown to significantly improve the recovery of viable bacteria from cow milk (Bradley et al., 2002). The objective of the current study, therefore, was to investigate the effect of freezing and a cryopreservant on the culture of bacteria in milk from meat sheep.

The study animals were a pedigree Charollais flock of 120 breeding ewes reared extensively on a UK lowland farm and lambed indoors. All samples were collected on a single day from a cohort of 50 ewes between 1 and 3 wk post-lambing. On average, the ewes were $3.3 \mathrm{yr}$ old and produced 1.76 lambs. Seven cases of clinical mastitis were detected in this lactation in this flock, giving a period prevalence of $5.8 \%$. Of these, 5 cases were acute 
and detected within $4 \mathrm{~d}$ post-lambing, the remaining 2 cases were chronic infections detected at weaning.

A total of 99 duplicate udder-half milk samples were collected using standard techniques (Hogan et al., 1999) and placed on ice. One sample, preserved with Bronopol, was submitted to a commercial laboratory (Quality Milk Management Services Ltd., UK) for SCC analysis using the Fossomatic method (model CombiScope FTIR 400; Delta Instruments BV, Drachten, the Netherlands) according to the FIL-International Dairy Federation 148 A: 95 norm (IDF, 1995), and the second was collected aseptically for microbiological analysis. An aliquot of this second sample was cultured immediately, with the remainder divided into 2 further samples, with approximately $10 \%$ (vol/vol) sterile glycerol added to one. Two $110-\mu \mathrm{L}$ aliquots were taken from each of these samples and stored at $-20^{\circ} \mathrm{C}$; a total of 5 aliquots were, therefore, made from each ewe half.

Milk samples were cultured according to recommended protocols (Hogan et al., 1999). Briefly, 100 $\mu \mathrm{L}$ of milk was spread across the surface of a brain heart infusion (BHI) agar plate supplemented with 5\% sterile sheep blood and incubated at $37^{\circ} \mathrm{C}$, with colony morphology recorded at 24 and 48 h. Samples with 5 or more distinct colony phenotypes were classed as contaminated. Microbiological growth was characterized using the $\mathrm{KOH}$ string, catalase, and tube-coagulase tests. Gram-positive, catalase-negative cultures were classified as Streptococcus-like; gram-positive, catalasepositive, tube-coagulase-positive isolates as Staph. aureus; and gram-positive, catalase-positive, tube-coagulase negative isolates as CNS. Mannheimia haemolytica and E. coli were identified by species-specific PCR (Riffon et al., 2001; Guenther et al., 2008). Bacterial genomic DNA was isolated using a modified Chelex protocol (de Lamballerie et al., 1992): $1 \mathrm{~mL}$ of overnight culture was pelleted and resuspended in $100 \mu \mathrm{L}$ of $5 \%$ Chelex (Bio-Rad Laboratories Ltd., Hertfordshire, UK) and $10 \mu \mathrm{L}$ of proteinase $\mathrm{K}(10 \mathrm{mg} / \mathrm{mL})$. The solution was incubated rotating at $56^{\circ} \mathrm{C}$ for $5 \mathrm{~h}$, centrifuged at $14,100 \times g$ for 3 min and the DNA-containing supernatant placed in a fresh tube. Deoxyribonucleic acid isolation was confirmed by amplification of a 438-bp fragment of the $23 \mathrm{~S}$ rRNA coding region, using primers Uni_1870 and Uni_2308; E. coli isolates were identified using primers Eco_2083 and Eco_2795 (Riffon et al., 2001); and M. haemolytica isolates were identified using primers Mhaem_306 and Mhaem_449 (Guenther et al., 2008).

The identity of a random selection of 17 gram-positive isolates was confirmed by partial sequencing of the 16S gene region. A 1,068-bp fragment was amplified with primers XB1 and XB4 (Moore et al., 2008) and sequenced using internal primers PSL and PSR (Moore et al., 2008) and BigDye chemistry on a 3130xl Genetic Analyzer (Applied Biosystems, Warrington, UK). Forward and reverse DNA sequences were aligned in the BioEdit program (Hall, 1999) to generate a consensus sequence for each isolate. This was compared with the GenBank database using the megablast function of nucleotide blast (http://blast.ncbi.nlm.nih.gov), and sequence identity determined using a similarity of $97 \%$ or higher (Stackebrandt and Goebel, 1994).

Fifty of the 99 samples with a range of bacterial species were selected for culture at 4 and 8 wk. All samples containing Staph. aureus and a representative subset of those containing Streptococcus-like, CNS, M. haemolytica, and E. coli were selected to approximate the proportion of isolates that were present in the full sample set, albeit with a slight reduction in CNS, but an increase in all other species.

The data were analyzed in 5 treatment groups: time zero (0), 4 wk frozen with glycerol $(4 \mathrm{G}+), 4$ wk frozen without glycerol $(4 \mathrm{G}-)$, 8 wk frozen with glycerol $(8 \mathrm{G}+)$, and 8 wk frozen without glycerol $(8 \mathrm{G}-)$, and categorized by the number of detected $\mathrm{cfu} / \mathrm{mL}(0, \leq 10$, 11 to 100 , and >100). We defined samples as positive if they yielded growth in any of the treatment groups. The effect of treatment group on bacterial recovery was tested using Fisher exact tests by comparing the proportion of the 50 samples positive in each treatment group with the proportion of samples positive in all other treatment groups and overall.

Of the 99 samples, 2 were contaminated and 5 yielded no growth. In the remaining 92 samples, 23, $85,9,6$, and 3 were positive for Streptococcus-like isolates, CNS, Staph. aureus, M. haemolytica, and E. coli, respectively. Seventy-five samples had SCC at time zero; of these, 4 were culture-negative, 42 yielded CNS with no other pathogen group, 5 yielded Staph. aureus (3 also contained CNS), 14 yielded Streptococcus-like isolates (11 also contained CNS), 2 contained E. coli (both contained CNS), and 1 yielded M. haemolytica in pure culture. The mean SCC of $1.2 \times 10^{6}$ cells $/ \mathrm{mL}$ was comparable to those reported in dairy and meat sheep flocks (González-Rodríguez et al., 1995; Gonzalo et al., 2002; Hariharan et al., 2004), and higher in samples containing $>100 \mathrm{cfu} / \mathrm{mL}$ (Figure 1).

No sample contained isolates in more than 3 of the described pathogen groups, although $8.1 \%$ of samples yielded up to 4 isolates, mainly due to the phenotypic diversity of CNS. Although many pathogen species were detected, none of the sheep had overt signs of mastitis and a large proportion of the samples contained fewer than $100 \mathrm{cfu} / \mathrm{mL}$; it is likely that had we used a $10-\mu \mathrm{L}$ inoculation volume, many samples would have been classed as bacteriologically negative. Indeed, using a $1,000 \mathrm{cfu} / \mathrm{mL}$ cutoff as indicative of infection, as em- 
4852

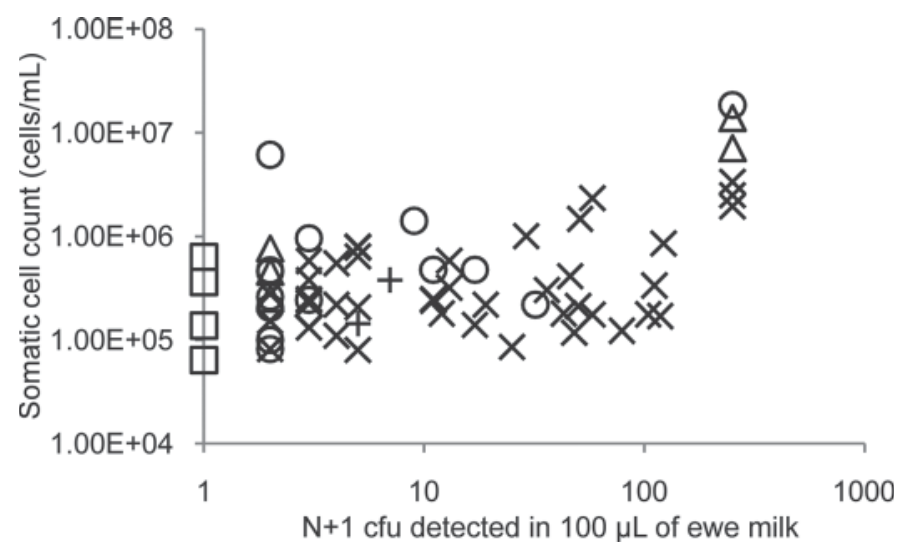

Figure 1. Somatic cell count by bacterial concentration of ewe milk samples that were culture negative $(\mathrm{n}=4$; squares), contained Streptococcus-like isolates $(\mathrm{n}=14$; circles), Staphylococcus aureus ( $\mathrm{n}$ $=5$; triangles), CNS ( $\mathrm{n}=42$; diagonal crosses $),$ Escherichia coli $(\mathrm{n}=$ 2 ; horizontal crosses), or Mannheimia haemolytica ( $\mathrm{n}=1$; diamond) at time zero. The log bacterial concentration +1 allows inclusion of culture-negative samples. The 6 samples with the highest bacterial concentration yielded growth that was too numerous to count and have been plotted at $250 \mathrm{cfu} / \mathrm{mL}$.

ployed by Watkins et al. (1991), results in $16(16.2 \%)$ samples (udder halves) being classed as positive, all in pure culture. This is comparable to the $13.2 \%$ of glands that were bacteriologically positive in the earlier study (Watkins et al., 1991).

Coagulase-negative staphylococci were virtually ubiquitous, being present in $92.4 \%$ of samples, and $100 \%$ of samples with 2 or 3 pathogen groups $(\mathrm{n}=22$ and $n=6$ respectively). Gram-positive isolates were more likely to be present with increasing numbers of pathogen groups. Escherichia coli was detected only in a mixed culture with CNS $(\mathrm{n}=2)$, and $M$. haemolytica was detected both in pure culture $(\mathrm{n}=2)$ and with 2 other bacterial groups $(\mathrm{n}=4)$. This relationship was also influenced by bacterial load; a nonsignificant tendency existed for plates with more colonies to contain fewer pathogen groups $(1 / 16$ plates where $>100 \mathrm{cfu}$ were counted had a mixed infection). This may be due to operator error because when more colonies were on a plate, it was more difficult to identify colonies that were phenotypically different. Alternatively, if high cfu were linked to high SCC, the udder might have been protected against a second bacterial species infecting the udder, as reported in dairy cows (Nickerson and Boddie, 1994; Schukken et al., 1999).

The 50 samples selected for further analysis included 2 contaminated samples, 4 bacteriologically negative samples and 15, 38, 9, 5, and 2 where Streptococcus-like isolates, CNS, Staph. aureus, M. haemolytica, and E. coli, respectively, were cultured at time zero (Table 1). Eight CNS, 5 Staph. aureus, and 2 streptococci were confirmed by sequencing; a further 2 Streptococcus-like isolates were identified as Aerococcus spp. The potential for misclassification of catalase-negative, grampositive cocci from milk samples has been described elsewhere (Fortin et al., 2003); however, the characterization of gram-positive, catalase-negative isolates as Streptococcus-like was sufficient for the current study. All resultant DNA sequences have been deposited in GenBank under accession numbers HM003050 to HM003066.

Using the results of culture at time zero as the gold standard, freezing with and without glycerol had a negative effect on the proportion of culture-positive samples across all species combined. Samples $<100 \mathrm{cfu} /$ $\mathrm{mL}$ were more likely to be negative in later treatment groups than those above this threshold (Figure 2). Only samples containing $>100 \mathrm{cfu}$ of Staph. aureus $/ \mathrm{mL}$ at time zero $(\mathrm{n}=4)$ were detectable at this concentration throughout the study. The concentration of Streptococcus-like isolates and CNS, although high initially in some samples, was lower after freezing. For all grampositive isolates, samples that were culture-negative at time zero were more likely to yield detectable growth after 4 rather than 8 wk storage, but the addition of glycerol had inconsistent effects (Figure 2).

Table 1. Number (\%) of samples culture positive by bacterial group or species in each treatment group with the number of samples ever positive as the denominator

\begin{tabular}{|c|c|c|c|c|c|c|c|}
\hline $\begin{array}{l}\text { Treatment } \\
\text { group }^{1}\end{array}$ & Streptococcus-like & CNS & $\begin{array}{c}\text { Staphylococcus } \\
\text { aureus }\end{array}$ & $\begin{array}{l}\text { Mannheimia } \\
\text { haemolytica }\end{array}$ & $\begin{array}{l}\text { Escherichia } \\
\text { coli }\end{array}$ & $\mathrm{NGD}^{2}$ & Cont. $^{3}$ \\
\hline 0 & $15\left(65.2^{\mathrm{ab}}\right)$ & $38\left(84.4^{\mathrm{ab}}\right)$ & $9(75.0)$ & $5(100.0)$ & $2\left(33.3^{\mathrm{ab}}\right)$ & $4\left(25.0^{\mathrm{a}}\right)$ & $2(100.0)$ \\
\hline $4 \mathrm{G}+$ & $10\left(43.5^{\mathrm{a}}\right)$ & $34\left(75.6^{\mathrm{a}}\right)$ & $7(58.3)$ & $3(60.0)$ & $2\left(33.3^{\mathrm{ab}}\right)$ & $9\left(56.3^{\mathrm{ab}}\right)$ & $0(0.0)$ \\
\hline $8 \mathrm{G}+$ & $7\left(30.4^{\mathrm{a}}\right)$ & $33\left(73.3^{\mathrm{a}}\right)$ & $6(50.0)$ & $3(60.0)$ & $2\left(33.3^{\mathrm{ab}}\right)$ & $10\left(62.5^{\mathrm{ab}}\right)$ & $0(0.0)$ \\
\hline $8 \mathrm{G}-$ & $7\left(30.4^{\mathrm{a}}\right)$ & $33\left(73.3^{\mathrm{a}}\right)$ & $8(66.7)$ & $2(40.0)$ & $1\left(16.7^{\mathrm{ab}}\right)$ & $11\left(68.8^{\mathrm{ab}}\right)$ & $0(0.0)$ \\
\hline All & $23\left(100.0^{b}\right)$ & $45\left(100.0^{b}\right)$ & $12(100.0)$ & $5(100.0)$ & $6\left(100.0^{b}\right)$ & $16\left(100.0^{b}\right)$ & $2(100.0)$ \\
\hline
\end{tabular}

${ }^{\mathrm{a}, \mathrm{b}}$ Detection sensitivities within a column with different superscripts differ $(P<0.05)$.

${ }^{1} 0$ : time $0 ; \mathrm{G}+$ : samples with $10 \%$ (vol/vol) glycerol added before freezing; $\mathrm{G}-$ : samples with no glycerol added; all: sum of the positive results of the 50 samples from all treatment groups. The numbers before the $\mathrm{G}+$ and $\mathrm{G}$ - indicate how many weeks the samples were stored frozen.

${ }^{2}$ No growth detected.

${ }^{3}$ Contaminated samples. 


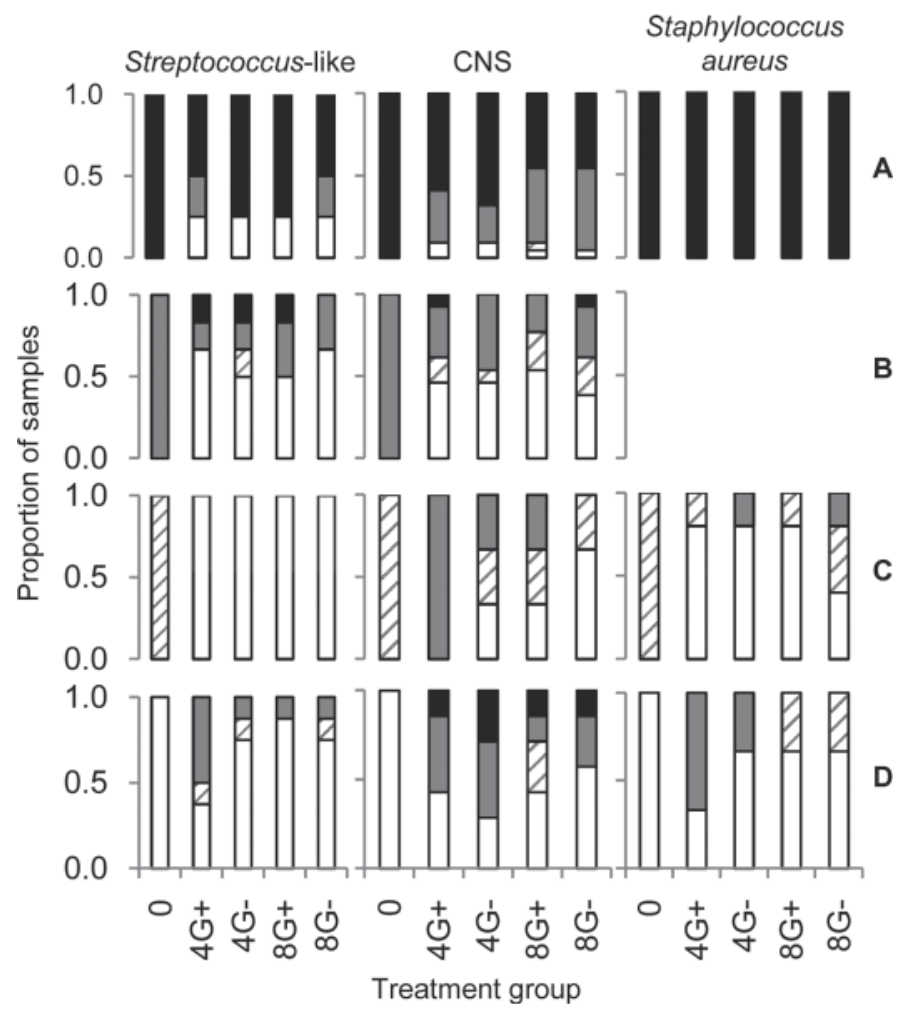

Figure 2. The proportion of samples containing gram-positive pathogens that were culture negative (white bars), yielded $\leq 10 \mathrm{cfu} /$ $\mathrm{mL}$ (diagonal lines), 11 to $100 \mathrm{cfu} / \mathrm{mL}$ (gray bars), or $>100 \mathrm{cfu} / \mathrm{mL}$ (black bars) from those originally containing $>100 \mathrm{cfu} / \mathrm{mL}$ (row A), 11 to $100 \mathrm{cfu} / \mathrm{mL}$ (row B), $\leq 10 \mathrm{cfu} / \mathrm{mL}$ (row C), or that were culture negative for that pathogen group (row D), in all treatment groups (0: time zero; $4 \mathrm{G}+$ : frozen for $4 \mathrm{wk}$ with glycerol; $4 \mathrm{G}-$ : frozen for $4 \mathrm{wk}$ without glycerol; $8 \mathrm{G}+$ : frozen for $8 \mathrm{wk}$ with glycerol; $8 \mathrm{G}-$ : frozen for $8 \mathrm{wk}$ without glycerol). Sample numbers (row A, B, C, D): Streptococcuslike isolates $(4,6,5,8)$; CNS $(22,13,3,7)$; Staphylococcus aureus $(4$, $0,5,3)$.

Of the 4 samples that were culture negative at time zero, 1 remained negative throughout, 2 were culture positive in 1 treatment group each $(4 \mathrm{G}+$ and $4 \mathrm{G}-$ ), and the remaining sample was positive in all 4 subsequent treatment groups. Only CNS were detected in these samples, and the treatment groups without glycerol yielded slightly higher colony counts (56 vs. $20 \mathrm{cfu} / \mathrm{mL}$ ). This suggests that if higher numbers of culture-negative samples had been present at time zero, the chance of finding a positive effect of freezing may have been increased. Further analysis of bacteriologically negative samples is required to see if this is the case.

The low prevalence of gram-negative isolates in the original samples and throughout the study is likely to be representative of the culturable pathogen distribution of the samples because they originated from a single farm. Two E. coli, and 5 M. haemolytica were detected at time zero. Escherichia coli was never detected again in these
2 samples; however, a further 4 were detected later; all 4 were detected in glycerol-supplemented samples, and 1 also in milk frozen without a cryopreservant. Of the 5 samples positive for $M$. haemolytica at time zero, 2 with 11 to $100 \mathrm{cfu} / \mathrm{mL}$ were undetectable thereafter; 2 that initially contained $>100 \mathrm{cfu} / \mathrm{mL}$ were detected in 3 and 4 of the 4 subsequent treatment groups. Glycerol supplementation increased isolation of gram-negative pathogens, both culture positive and the number of cfu detected; however, the identification of $E$. coli- and $M$. haemolytica-positive samples was low and these results should be confirmed in a larger study.

Culture at time zero was the most sensitive method for detection of all bacteria, with a sensitivity that ranged from $33.3 \%$ (E. coli) to $100.0 \%$ (M. haemolytica; Table 1). No significant difference existed in the sensitivity of detection of any bacterial species at wk 4 and 8 compared with time zero. However, significantly fewer $(P<0.05)$ culture-negative samples were found at time zero compared with wk 4 and 8; and, when compared with the total number of samples ever positive, significantly fewer Streptococcus-like isolates and CNS $(P<0.05)$ were detected in wk 4 and 8 . For all isolates, a higher sensitivity was achieved by combining the results of fresh sample culture with subsequent treatment groups (Table 2). The combination of time zero plus 4 wk with glycerol increased the sensitivity of detection to above $85 \%$ for all species except $E$. coli.

Our original hypothesis was that the addition of $10 \%$ (vol/vol) glycerol, a commonly used cryoprotectant, to ovine milk before freezing would result in increased preservation of viable bacteria compared with unsupplemented samples, as demonstrated in cow milk (Bradley et al., 2002). It was surprising, therefore, that glycerol supplementation had no significant positive effect on pathogen isolation rates, although it did produce a small nonsignificant benefit when samples were frozen for $4 \mathrm{wk}$ compared with $8 \mathrm{wk}$. This was noticeable even though the addition of glycerol decreased the volume of milk plated by $10 \%$, and is similar to the effects of glycerol supplementation on Mycoplasma spp. recovery from frozen bovine milk (Boonyayatra et al., 2010).

Differences exist, however, between our study and the investigation into the effects of glycerol supplementation on the recovery of mastitis pathogens from frozen milk samples by Bradley et al. (2002). The most obvious difference was the source of milk samples: we used sheep rather than cow milk with double the percent solids, and our samples were naturally infected, rather than manually inoculated culture-negative milk samples. Differences also exist in the concentration of minerals in ewe and cow milk (Polychroniadou and Vafopoulou, 1985; Rodríguez Rodríguez et al., 2001) and these are likely to vary during an IMI. The effects of 
Table 2. Sensitivity (\%) of combinations of treatment groups for all bacterial groups or species with the number of samples ever positive as the denominator

\begin{tabular}{lccccc}
\hline $\begin{array}{l}\text { Treatment } \\
\text { group }^{1}\end{array}$ & Streptococcus-like & CNS & $\begin{array}{c}\text { Staphylococcus } \\
\text { aureus }\end{array}$ & $\begin{array}{c}\text { Mannheimia } \\
\text { haemolytica }\end{array}$ & $\begin{array}{c}\text { Escherichia } \\
\text { coli }\end{array}$ \\
\hline 0 & 65.2 & 84.4 & 75.0 & 100.0 & 33.3 \\
0 and 4G+ & 87.0 & 93.3 & 91.7 & 100.0 & 66.7 \\
0 and 8G+ & 69.6 & 93.3 & 83.3 & 100.0 & 66.7 \\
0 and 4G+ and 8G+ & 91.3 & 95.6 & 100.0 & 100.0 & 100.0 \\
0 and 4G- & 73.9 & 95.6 & 83.3 & 100.0 & 33.3 \\
0 and 8G- & 73.9 & 91.1 & 83.3 & 100.0 & 50.0 \\
0 and 4G- and 8G- & 82.6 & 95.6 & 83.3 & 100.0 & 50.0 \\
\hline
\end{tabular}

${ }^{1} 0$ : time $0 ; \mathrm{G}+$ : samples with $10 \%$ (vol/vol) glycerol added before freezing; $\mathrm{G}-$ : samples with no glycerol added.

The numbers before the $\mathrm{G}+$ and $\mathrm{G}$ - indicate how many weeks the samples were stored frozen.

milk composition on bacterial viability after a freezethaw cycle are unknown. One possible mechanism, postulated previously (Schukken et al., 1989), which may explain why some species grow better and others worse after freezing, is the response to the potential increase in mineral composition of milk, due to freezing extracellular water. This would expose bacterial cells to ice crystals and an osmotic gradient, which might lead to cell shrinkage and possibly cause membrane lesions.

The increased isolation rate of Staph. aureus (Villanueva et al., 1991; Sol et al., 2002) and CNS (Schukken et al., 1989) from bovine milk after freezing is believed to be due to the disruption of bacterial cell aggregates, and damage to phagocytic leukocytes during freezing and thawing, leading to the release of intracellular staphylococci (Schukken et al., 1989; Villanueva et al., 1991). It is possible, in the present study, that glycerol preserved host phagocytic cells, preventing release of intracellular bacteria, and thus, negated any improvement in the detection of CNS or Staph. aureus. However, samples without cryopreservant did not yield increased numbers of gram-positive bacteria.

Combining the results from treatment groups increased detection sensitivity for some species, as has been demonstrated with Staph. aureus and streptococci in cow milk (Sol et al., 2002). However, augmented culture (Dinsmore et al., 1992; Sol et al., 2002) and molecular techniques (Gillespie and Oliver, 2005; Koskinen et al., 2009) might represent a more effective method for detection of pathogens.

In conclusion, the supplementation of ovine milk samples with $10 \%$ sterile glycerol had no significant negative effect on the culture of milk stored frozen for 4 and 8 wk compared with unsupplemented samples, and may offer some protection to gram-negative organisms. Repeat analysis of samples improved the sensitivity of detection of all bacterial species. Further studies are required to fully determine the effects of freezing and cryopreservants on the culture of bacteria from meat sheep milk.

\section{ACKNOWLEDGMENTS}

This work was funded in part by a Wellcome Trust Value in People (VIP) Fellowship to E. M. Smith. We are also grateful to two anonymous reviewers for their suggestions on an earlier version of this manuscript.

\section{REFERENCES}

Arsenault, J., P. Dubreuil, R. Higgins, and D. Belanger. 2008. Risk factors and impacts of clinical and subclinical mastitis in commercial meat-producing sheep flocks in Quebec, Canada. Prev. Vet. Med. 87:373-393.

Boonyayatra, S., L. K. Fox, T. E. Besser, A. Sawant, and J. M. Gay. 2010. Effects of storage methods on the recovery of Mycoplasma species from milk samples. Vet. Microbiol. 144:210-213.

Bradley, A. J., M. J. Green, and J. N. Huxley. 2002. Making better use of milk samples: Monitoring and investigating herd mastitis. Cattle Pract. 10:105-112.

Clements, A. C., D. J. Taylor, and J. L. Fitzpatrick. 2003. Evaluation of diagnostic procedures for subclinical mastitis in meat-producing sheep. J. Dairy Res. 70:139-148.

de Lamballerie, X., C. Zandotti, C. Vignoli, C. Bollet, and P. de Micco. 1992. A one-step microbial DNA extraction method using "Chelex 100" suitable for gene amplification. Res. Microbiol. 143:785-790.

Dinsmore, R. P., P. B. English, R. N. Gonzalez, and P. M. Sears. 1992. Use of augmented cultural techniques in the diagnosis of the bacterial cause of clinical bovine mastitis. J. Dairy Sci. 75:2706-2712.

Fortin, M., S. Messier, J. Pare, and R. Higgins. 2003. Identification of catalase-negative, non-beta-hemolytic, gram-positive cocci isolated from milk samples. J. Clin. Microbiol. 41:106-109.

Fthenakis, G. C., and J. E. T. Jones. 1990. The effect of experimentally induced subclinical mastitis on milk yield of ewes and on the growth of lambs. Br. Vet. J. 146:43-49.

Gillespie, B. E., and S. P. Oliver. 2005. Simultaneous detection of mastitis pathogens, Staphylococcus aureus, Streptococcus uberis, and Streptococcus agalactiae by multiplex real-time polymerase chain reaction. J. Dairy Sci. 88:3510-3518.

González-Rodríguez, M. C., C. Gonzalo, F. San Primitivo, and P. Cármenes. 1995. Relationship between somatic cell count and intramammary infection of the half udder in dairy ewes. J. Dairy Sci. 78:2753-2759.

Gonzalo, C., A. Ariznabarreta, J. A. Carriedo, and F. San Primitivo, 2002. Mammary pathogens and their relationship to somatic cell count and milk yield losses in dairy ewes. J. Dairy Sci. 85:14601467.

Guenther, S., P. Schierack, M. Grobbel, A. Lübke-Becker, L. H. Wieler, and C. Ewers. 2008. Real-time PCR assay for the detection of species of the genus Mannheimia. J. Microbiol. Methods 75:75-80.

Hall, T. A. 1999. BioEdit: A user-friendly biological sequence alignment editor and analysis program for Windows 95/98/NT. Nucl. Acids Symp. Ser. 41:95-98. 
Hariharan, H., W. Donachie, C. Macaldowie, and G. Keefe. 2004. Bacteriology and somatic cell counts in milk samples from ewes on a Scottish farm. Can. J. Vet. Res. 68:188-192.

Hogan, J. S., R. N. Gonzalez, R. J. Harmon, S. C. Nickerson, S. P. Oliver, J. W. Pankey, and K. L. Smith. 1999. Laboratory Handbook on Bovine Mastitis. National Mastitis Council, Madison, WI.

IDF. 1995. Enumeration of somatic cells. FIL-IDF Standard no. 148A. International Dairy Federation, Brussels, Belgium.

Koskinen, M. T., J. Holopainen, S. Pyörälä, P. Bredbacka, A. Pitkälä, H. W. Barkema, R. Bexiga, J. Roberson, L. Sølverød, R. Piccinini, D. Kelton, H. Lehmusto, S. Niskala, and L. Salmikivi. 2009. Analytical specificity and sensitivity of a real-time polymerase chain reaction assay for identification of bovine mastitis pathogens. J. Dairy Sci. 92:952-959.

Moore, J. E., Y. Maeda, J. Xu, B. C. Millar, P. H. Herold, V. M. J. Browne-Lauwers, C. E. Goldsmith, A. Loughrey, P. J. Rooney, J. S. Elborn, and M. Matsuda. 2008. Employment of $16 \mathrm{~S}$ rDNA gene sequencing techniques for improved identification of difficultto-identify bacterial veterinary pathogens. World J. Microbiol. Biotechnol. 24:1227-1232.

Nickerson, S. C., and R. L. Boddie. 1994. Effect of naturally occurring coagulase-negative staphylococcal infections on experimental challenge with major mastitis pathogens. J. Dairy Sci. 77:2526-2536.

Polychroniadou, A., and A. Vafopoulou. 1985. Variations of major mineral constituents of ewe milk during lactation. J. Dairy Sci. 68:147-150.

Riffon, R., K. Sayasith, H. Khalil, P. Dubreuil, M. Drolet, and J. Lagacé. 2001. Development of a rapid and sensitive test for iden- tification of major pathogens in bovine mastitis by PCR. J. Clin. Microbiol. 39:2584-2589.

Rodríguez Rodríguez, E. M., M. Sanz Alaejos, and C. Diaz Romero. 2001. Mineral concentrations in cow's milk from the Canary Island. J. Food Compost. Anal. 14:419-430.

Schukken, Y. H., F. J. Grommers, J. A. Smit, D. Vandegeer, and A. Brand. 1989. Effect of freezing on bacteriologic culturing of mastitis milk samples. J. Dairy Sci. 72:1900-1906.

Schukken, Y. H., K. E. Leslie, D. A. Barnum, B. A. Mallard, J. H. Lumsden, P. C. Dick, G. H. Vessie, and M. E. Kehrli. 1999. Experimental Staphylococcus aureus intramammary challenge in late lactation dairy cows: Quarter and cow effects determining the probability of infection. J. Dairy Sci. 82:2393-2401.

Sol, J., O. C. Sampimon, E. Hartman, and H. W. Barkema. 2002. Effect of preculture freezing and incubation on bacteriological isolation from subclinical mastitis samples. Vet. Microbiol. 85:241249 .

Stackebrandt, E., and B. M. Goebel. 1994. Taxonomic note: A place for DNA-DNA reassociation and $16 \mathrm{~S}$ rRNA sequence analysis in the present species definition in bacteriology. Int. J. Syst. Bacteriol. 44:846-849.

Villanueva, M. R., J. W. Tyler, and M. C. Thurmond. 1991. Recovery of Streptococcus agalactiae and Staphylococcus aureus from fresh and frozen bovine milk. J. Am. Vet. Med. Assoc. 198:1398-1400.

Watkins, G. H., A. R. Burriel, and J. E. T. Jones. 1991. A field investigation of subclinical mastitis in sheep in southern England. Br. Vet. J. 147:413-420. 